\title{
ANALISIS USABILITY PADA APLIKASI BERBASIS WEB \\ DENGAN MENGADOPSI MODEL KEPUASAN PENGGUNA (USER SATISFACTION)
}

\author{
Sigit Hadi Prayoga ${ }^{1}$ dan Dana Indra Sensuse ${ }^{2}$
}

${ }^{1}$ Enterprise Solution, $R \& D$ Center PT. TELKOM, Jalan Japati No. 1, Bandung, 40133, Indonesia

${ }^{2}$ Fakultas Ilmu Komputer, Universitas Indonesia, Kampus Baru UI Depok, Jawa Barat, 16424, Indonesia

E-mail: sigit_hp@telkom.co.id

\begin{abstract}
Abstrak
Iklim persaingan antar perusahaan telekomunikasi yang saat ini semakin kuat sangat terkait dengan mekanisme perusahaan dalam memberikan layanan purna jual atas jasa yang diberikan serta bagaimana perusahaan dapat membuka hubungan langsung dengan pelanggannya. Perusahaan membangun suatu cara yang dapat menjaga loyalitas pelanggannya. Pendekatan tren teknologi yang dapat menyajikan layanan ini adalah melalui CRM (Customer Relationship Management). Analisis usability pada aplikasi berbasis web dengan mengadopsi model penerimaan pengguna aplikasi, difokuskan pada analisis aspek usability pengguna yang bertindak sebagai pelanggan yang menikmati produk dan layanan suatu perusahaan. Saat ini, sudah cukup banyak teori model penerimaan pengguna terhadap suatu aplikasi. Salah satunya adalah dengan model kepuasan pengguna (User Satisfaction). Pengumpulan data dilakukan dengan survei kepuasan pengguna terhadap aplikasi. Berdasar pada landasan teori yang ada, uji statistik pada model kepuasan pengguna memanfaatkan teori Structural Equation Model (SEM) dan perangkat lunak LISREL 8.80. Hasil penelitian menemukan beberapa kaitan antara variabel laten pengukuran dengan variabel lainnya.Penelitian ini secara khusus menemukenali pula bahwa sajian content memberikan pengaruh positif secara signifikan terhadap kepuasan pengunjung website, dibanding aspek Ease of Use, Customization dan Download Delay. Hasil penelitian juga menghasilkan rekomendasi perbaikan atas aplikasi yang diharapkan dapat meningkatkan kemanfaatan (usability) aplikasi.
\end{abstract}

Kata Kunci: usability, user satisfaction, web

\begin{abstract}
The Atmosphere of competition among telecommunications companies that are currently growing strongly associated with the mechanism of the company in providing after-sales service for services given and how the company can open a direct relationship with customers. Company builds a way that can keep the loyalty of its customers. Approach to technology trends that can provide these services are through the CRM (Customer Relationship Management). Analysis of usability in web-based applications by adopting a model of user acceptance of applications, focused on the analysis of usability aspects of the user who acts as the customer who enjoys the company's products and services. Currently, there are some theoretical models of user acceptance of an application. One way is to model user satisfaction (User Satisfaction). The data was collected with a user satisfaction survey of the application. Based on the existing foundation theory, statistical tests on the model of user satisfaction utilizing the theory of Structural Equation Model (SEM) and LISREL 8.80 software. The study found some association between the latent measurements variables with other variables. This study specifically identifies that the content provided also provides a significantly positive influence on satisfaction of website visitors, than the aspect of Ease of Use, Customization and Download Delay. The results also generate recommendations for improvement for applications that are expected to increase the usefulness (usability) applications.
\end{abstract}

Keywords: usability, user satisfaction, web

\section{Pendahuluan}

Kehadiran teknologi informasi dalam mendukung kegiatan sehari-hari semakin terasa manfaatnya. Penggunaan web sebagai media untuk membaca berita, mencari pekerjaan, berbelanja online dan merencanakan perjalanan, merupakan beberapa aktivitas yang umumnya banyak dilakukan oleh masyarakat. Bagi pelanggan bisnis, layanan Corporate Customer Care, Internet Banking, Reservasi Hotel online, pengelolaan bisnis proses internal perusahaan 
sampai ke aplikasi e-learning, merupakan beberapa contoh aplikasi yang memanfaatkan media web.

Aplikasi berbasis web digunakan pula oleh perusahaan untuk mendukung aktivitas pemasaran produk dan layanannya. Salah satunya adalah dengan hadirnya website perusahaan di internet yang berisi informasi produk dan layanan perusahaan tersebut. Beberapa website bahkan menyajikan layanan edukasi kepada pelanggan perusahaan sebagai upaya membangun loyalitas pelanggan. Aktivitas tersebut kini lebih dikenal sebagai bagian dari solusi CRM (Customer Relationship Management).

Dalam suatu riset yang dilakukan oleh International Data Corporation (IDC) pada bulan Maret tahun 2009 lalu, terlihat bahwa perusahaan saat ini semakin menyadari dan memahami pentingnya CRM (Customer Relationship Management) dalam membangun bisnis mereka. Hal ini ditandai dengan prediksi meningkatnya implementasi layanan CRM pada perusahaan di tahun 2013 sebagaimana terlihat pada gambar 1 . Salah satu aplikasi yang dijadikan bahan analisis pada penulisan ini adalah aplikasi yang dikembangkan sebagai media sosialisasi sekaligus edukasi produk dan layanan suatu perusahaan.

Sebagai media edukasi, maka informasi yang disajikan tidak saja mengenai produk dan layanan tersebut, namun lebih menekankan pada sarana interaktif untuk melakukan simulasi penggunaan produk dan layanan tersebut oleh pengguna.

Manajemen perusahaan sangat mengharapkan bahwa aplikasi ini dapat disajikan kepada masyarakat sebagai media interaktif. Untuk itu, sikap penerimaan terhadap aplikasi ini di kalangan internal perusahaan, menjadi salah satu tolak ukur bagi manajemen perusahaan untuk dapat meluncurkan layanan ini kepada masyarakat. Dengan melakukan evaluasi lebih dini, perusahaan dapat mengantisipasi kemungkinan buruk yang dapat terjadi dan meminimalkan dampak negatif yang timbul.

Penelitian ini kemudian dilakukan untuk menganalisis aspek usability yang memengaruhi sikap penerimaan pengguna sistem terhadap Aplikasi. Manfaat Aplikasi diukur berdasarkan parameter-parameter kepuasan pengguna (User Satisfaction) terhadap aplikasi. Kecenderungan sikap penolakan atau penerimaan terhadap aplikasi melalui kegiatan survei diharapkan dapat memberikan masukan untuk penyempurnaan aplikasi ini dikemudian hari.

Saat ini banyak sekali website yang menyajikan beragam informasi. Namun demikian, banyak pula di antara website tersebut yang tidak dapat memenuhi tujuan awal kenapa website tersebut dibuat dan bahkan sangat banyak yang mengecewakan pengguna yang mengaksesnya. Menurut penelitian yang dilakukan oleh User Interface Engineering, Inc., diketahui bahwa $60 \%$ waktu terbuang karena orang tidak bisa menemukan informasi yang ingin didapatnya pada suatu website dan hal ini berdampak pada penurunan produktivitas, meningkatkan frustasi, dan bentuk kerugian lainnya [1].

Berdasarkan fakta tersebut, pengguna umumnya memberikan penilaian subjektif bahwa website tersebut sudah tidak pantas untuk dikunjungi lagi. Jika hal ini terjadi kepada banyak pengguna, maka sudah dapat dipastikan bahwa website tersebut akan ditinggalkan banyak orang sehingga akan berakibat gagalnya pencapaian tujuan awal pembuatan website itu sendiri. Kerugian lain yang bisa terjadi adalah kehilangan keuntungan yang mungkin dapat diperoleh, atau bahkan berakibat paling buruk berupa ditutupnya website tersebut.

Berdasarkan hasil studi yang dilakukan Forrester Research, dinyatakan bahwa sekitar $50 \%$ dari potential sales hilang karena pengguna tidak bisa menemukan informasi dan $40 \%$ dari pengguna tidak kembali lagi mengunjungi website karena pengalaman buruk ketika pertama kali mengunjungi website tersebut [1]. Oleh karena itu, sikap penerimaan terhadap aplikasi oleh pengguna patut menjadi pertimbangan dalam mengimplementasikan aplikasi tersebut dikemudian hari.

Penerimaan dan penggunaan aplikasi oleh user terhadap suatu teknologi, sangat dipengaruhi oleh faktor internal dan eksternal. Faktor eksternal meliputi kondisi yang memfasilitasi atau menghambat sikap penggunaan IT, sedangkan faktor internal berfokus pada proses perencanaan dalam individu pengguna yang diliputi oleh pertimbangan untuk akhirnya memutuskan memanfaatkan IT atau tidak [2].

Untuk memudahkan mendapatkan pemahaman mengenai permasalahan utama yang akan diteliti dalam penelitian ini, serta untuk memudahkan tujuan penelitian ini, maka permasalahan utama penelitian ini akan dipecah menjadi beberapa permasalahan sebagai berikut:

Pertama, Aspek-aspek apa saja yang perlu diperhatikan dalam analisis usabilility terhadap aplikasi berbasis web?

Kedua, Variabel-variabel apa saja yang memengaruhi penerimaan user terhadap Aplikasi dalam kerangka Usability?

Ketiga, Bagaimana hubungan antar faktor tersebut yang menggambarkan penerimaan dan penggunaan Aplikasi ? 


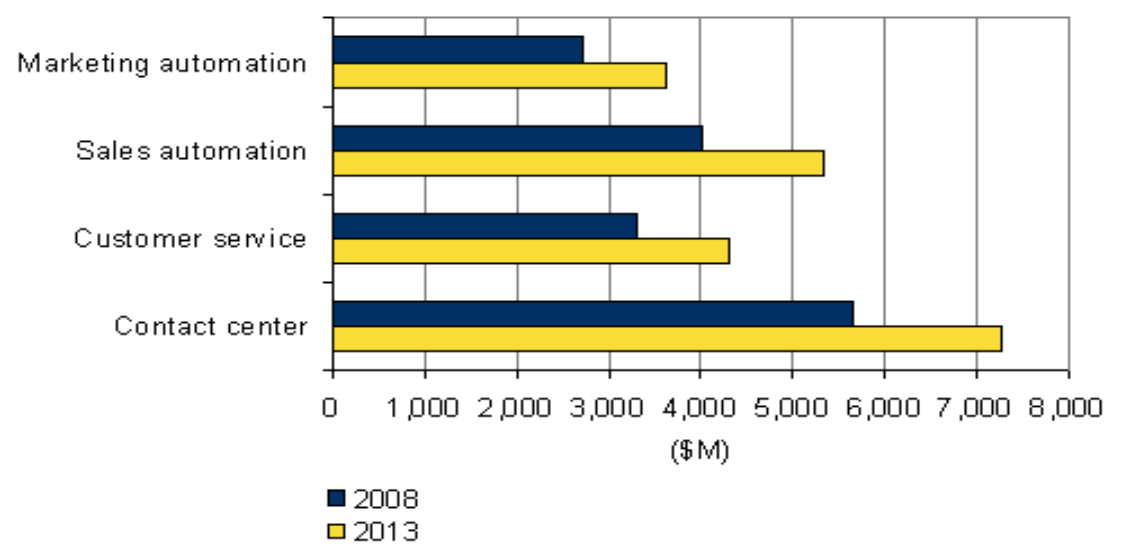

Gambar 1. Tren pertumbuhan aplikasi berbasis CRM 2008-2013.

Dengan mengacu pada perumusan masalah, maka tujuan penelitian ini untuk mengetahui aspek-aspek apa saja yang perlu diperhatikan dalam melakukan pengembangan aplikasi berbasis web, mengetahui variabel-variabel apa saja yang mempengaruhi penerimaan pengguna terhadap Aplikasi dalam kerangka Usability, mengetahui bagaimana keterhubungan variabelvariabel tersebut dengan penerimaan pengguna terhadap Aplikasi.

Usability diartikan sebagai proses optimasi interaksi antara pengguna dengan sistem yang dapat dilakukan dengan interaktif, sehingga pengguna mendapatkan informasi yang tepat atau menyelesaikan suatu aktivitas pada aplikasi tersebut dengan lebih baik [3]. Agar suatu aplikasi menjadi efektif, efisien dan dapat memberikan kepuasan kepada pengguna, maka aplikasi tersebut harus dapat memberikan kesempatan kepada pengguna untuk menyelesaikan aktivitasnya pada aplikasi tersebut sebaik mungkin.

Menurut Landauer [4], sebagian besar total biaya pengembangan perangkat lunak digunakan untuk perawatan karena permasalahan interaksi (usability) pengguna dengan sistem dan bukan permasalahan teknis. Situasi tersebut diatas menggambarkan pentingnya analisis usability untuk mempertegas kebutuhan terhadap pengembangan aplikasi, sebelum, pada saat, dan sesudah proses pengembangan perangkat lunak [5].

Peneliti lainnya, Nielsen [6] mendefinisikan usability sebagai suatu pengalaman pengguna dalam berinteraksi dengan aplikasi atau situs web sampai pengguna dapat mengoperasikannya dengan mudah dan cepat. Nielsen [6] juga merumuskan faktor-faktor penyebab pentingnya website memiliki aspek usability, diantaranya adalah kebiasaan atau perilaku pengguna yang mengakses website. Tidak sedikit pengguna yang tidak dapat menerima design website yang buruk dan mau meluangkan waktu untuk mempelajari suatu website atau dengan kata lain, pengguna sangat ingin segera mengerti dengan seketika (instant), atas apa yang disajikan dalam suatu website.

Setelah melakukan kajian tentang usability secara umum, maka selanjutnya perlu dilakukan kajian bagaimana melakukan pengukuran usability pada website. Secara umum kriteria yang menentukan bahwa sebuah website usable (memiliki tingkat usability yang tinggi) adalah apabila pengguna bisa menemukan atau memperoleh apa yang mereka butuhkan dan mengerti dari website tersebut [1].

Menurut Nielsen [6], ada lima syarat yang harus dipenuhi agar suatu website mencapai tingkat usability yang ideal, yaitu learn ability, efficiency, memorability, errors, satisfaction. Learn ability menjelaskan ukuran bagi pengguna dalam memahami kebiasaan mengunjungi suatu website, mengetahui alasan mengakses dan mengidentifikasi yang dicari.Efficiency mejelaskan bahwa situs yang efisien dapat menyajikan informasi dengan cepat. Memorability menjelaskan ukuran bagi pengguna, sehingga website akan mudah diingat. Bila website banyak dilakukan perubahan, maka pengunjung akan memerlukan waktu untuk menyesuaikan dan mempelajarinya kembali.Errors adalah menghindari adanya link yang tidak berfungsi (broken link) atau halaman web yang masih dalam proses pembuatan (under construction).Satisfaction adalah hal yang paling diinginkan oleh setiap pengguna. Pengunjung menginginkan situs dapat dengan mudah digunakan dan dipelajari. Selain itu mereka ingin bisa menemukan apa yang dicari dengan cepat, mengetahui di mana mereka berada dan bisa pergi ke mana saja dalam sebuah situs. 
Dalam penelitian lain, Dix [7] menyampaikan empat kriteria dalam melakukan kajian usability. Keempat kriteria tersebut adalah Effectiveness, Efficiency, Satisfaction dan Learnability.

Lembaga

\section{Internatioal}

Standard

Organization (ISO) kemudian melakukan konsolidasi pengukuran Usability dengan melihat pada kriteria pengukuran Usability Nielsen [6], Dix [7], standar ISO 9126 \& ISO 14598 (Usability berorientasi pada product) dan standar ISO 9241 \& ISO 13407 (Usability berorientasi pada proses). Hasil konsolidasi tersebut, melahirkan suatu model konsolidasi Usability, dengan lima parameter pengukuran yaitu effectiveness, efficiency, satisfaction, learnability, security [8].

Baik Usability Model yang dikeluarkan oleh lembaga standar ISO, Nielsen [6], Dix [7], seluruhnya mencantumkan perlunya pengukuran terhadap kepuasan pengguna sebagai bagian dari parameter Usability. Hal ini menarik perhatian peneliti, terlebih lagi setelah ditemukannya penelitian lebih lanjut terkait kepuasan pengunjung website dalam konteks Usability.

Palmer [9], yang kemudian dikenal sebagai pakar dalam Human-Computer Interaction, pada tahun 2002 telah berhasil mengembangkan konstruk untuk Usability website yaitu waktu penerimaan data (Download Delay), pengelolaan navigasi halaman (Navigation / Organization), interaktivitas (Interactivity), responsivitas (Responsiveness), informasi materi website (Information atau Content), website yang berhasil (User Satisfaction).

Selang waktu penerimaan data (Download Delay). Parameter yang diukur adalah kecepatan awal akses dan kecepatan tampilan antar halaman. Pengelolaan navigasi halaman (Navigation / Organization). Parameter yang diukur adalah pengaturan, urutan halaman, links, layout dan pengelolaan dan penempatan navigasi. Interaktivitas (Interactivity). Parameter yang diukur adalah customhalaman web dan interaktivitas. Responsivitas (Responsiveness). Parameter yang diukur adalah fasilitas Feedback dan FAQ. Informasi materi website (Information atau Content). Parameter yang diukur adalah jumlah informasi, keragaman informasi, jumlah kata, dan kualitas materi website. Website yang berhasil (User Satisfaction). Parameter yang diukur adalah kepuasan pengguna, keinginan untuk mengakses kembali website dan frekuensi mengakses website. Dari keenam konstruk tersebut, Palmer [9] menggambarkan kaitannya dalam suatu model penelitian untuk usability sebagaimana pada gambar 2 .

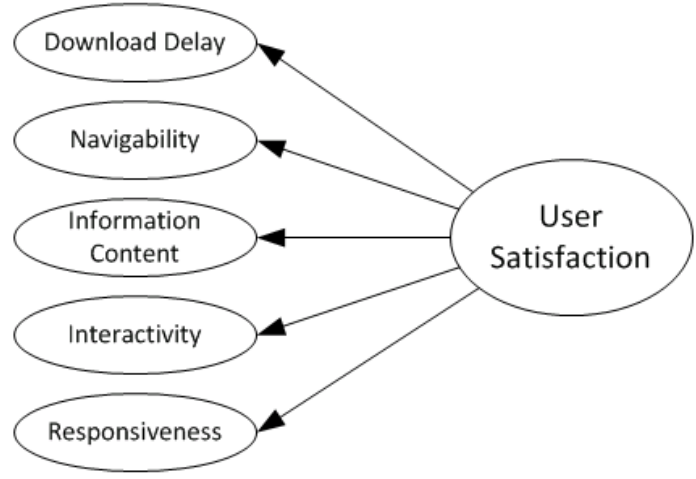

Gambar 2. Model usability Palmer [9].

Agarwal dan Venkatesh [10], menyampaikan pula konsep pengukuran usability berdasarkan pendekatan yang dikeluarkan oleh Microsoft UsabilityGuideline. Pada penelitiannya, mereka menyusun kategori dan subkategori usability dengan skema pembobotan (weights) dan pemeringkatan (rating).

Model Penelitian Agarwal dan Venkatesh [10] tersebut, cukup banyak dijadikan referensi sebagai pembanding dengan model penelitian lainnya, khususnya dalam kajian usability. Beberapa diantaranya adalah Green dan Pearson [11] yang melakukan perbandingan model Agarwal dan Venkatesh dengan model Palmer melalui metoda Confirmatory Factor Analysis (CFA). Hasil dari penelitian tersebut menunjukkan bahwa hasil CFA model Palmer yang lebih memenuhi standar yang direkomendasikan.

Dalam penelitian lanjutannya di tahun 2008, Green dan Pearson melakukan kajian dengan membandingkan Model Penelitian Usability Palmer dan Model Penelitian Agarwal dan Venkatesh terhadap suatu website [12]. Dari kesimpulan yang dicapai pada penelitian kedua, Green dan Pearson [12] merumuskan empat dimensi terbaik untuk mengukur kepuasan pengguna terhadap suatu website, yaitu dengan menentukan variabel pengukuran yang dinilai memiliki nilai yang lebih kuat (robust) namun sangat sesuai (parsimonious). Keempat variabel pengukuran tersebut adalah : kemudahan (Ease of Use), personalisasi (Customization), kecepatan akses pada aplikasi (Download Delay), informasi (Content)

Keempat konstruk inilah yang kemudian menjadi bahan pertimbangan peneliti untuk dilakukan pengujian pada website Aplikasi, yang akan dibahas kemudian pada bagian metodologi. Dari penelitian tersebut, selain didapat empat konstruk yang memberikan nilai signifikan terhadap validitas pengujian, juga didapat suatu model penelitian yang menyimpulkan bahwa kepuasan pengguna (User Satisfaction) dalam 
mengakses website menjadi variabel endogen yang dapat mendorong pengunjung untuk mengakses kembali website tersebut. Pada gambar 3 disajikan model penelitian Green dan Pearson [11] sebagai rujukan untuk penelitian selanjutnya terkait usablility.

\section{Metodologi}

Penelitian ini dilaksanakan untuk mengetahui kemanfaatan (Usability) pada suatu Aplikasi di perusahaan. Penelitian ini merupakan penelitian survei, yaitu penelitian yang mengambil sampel secara langsung dari populasi. Dilihat dari permasalahan yang diteliti, penelitian ini merupakan penelitian kausalitas, yang bertujuan untuk menganalisis hubungan dan pengaruh (sebab-akibat) dari dua atau lebih fenomena [13] melalui pengujian hipotesis.

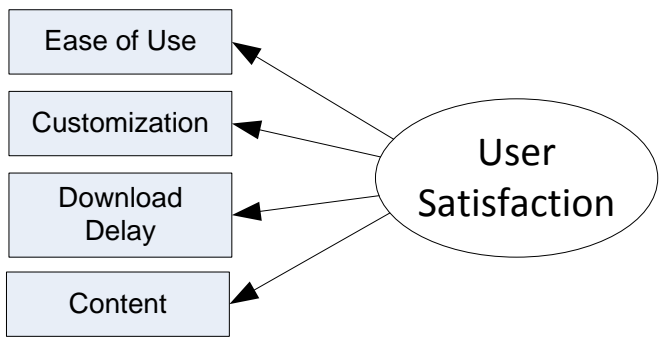

Gambar 3. Model penelitian Green and Pearson [11].

Subjek penelitian ini adalah karyawan yang telah menggunakan produk dan layanan perusahaan. Penelitian ini dilakukan di Indonesia dan dalam kurun waktu 2 bulan, yaitu Juni 2009 sampai dengan Agustus 2009.

Cooper dan Schindler [14] mengungkapkan bahwa penelitian yang mendasarkan pada teori atau hipotesis yang akan dipergunakan untuk menguji suatu fenomena yang terjadi digolongkan pada jenis penelitian eksplanatori (penjelasan). Penelitian eksplanatori melakukan studi terhadap hubungan antara dua atau lebih variabel, kemudian berusaha untuk menjelaskan fenomena yang terjadi.

Sampel merupakan elemen populasi yang dipilih untuk mewakili populasi dalam penelitian [13]. Pengambilan sampel dalam penelitian ini menggunakan random sampling yaitu pengambilan sampel yang memberikan kesempatan yang sama untuk diambil kepada setiap elemen populasi. Metode ini juga menggunakan kriteria untuk sampelnya. Kriteria yang ditetapkan tersebut adalah orang-orang yang memiliki Nomor Induk Karyawan (NIK) berupa data login dan password portal internal perusahaan.
Cara pengumpulan data dilakukan dengan metode survei kuesioner pada pengguna Aplikasi. Survei dilakukan untuk mendapatkan umpan balik atas persepsi pengguna terhadap Aplikasi. Data yang digunakan dalam penelitian ini adalah data primer, yaitu data yang diperoleh langsung dari kuesioner yang disajikan secara online pada portal perusahaan. Peneliti menggunakan media Web Intranet sebagai media untuk penyebaran kuesioner kepada responden yang menjadi sampel penelitian ini.

Dalam penelitian ini, besarnya sampel disesuaikan dengan model analisis yang digunakan yaitu Structural Equation Model (SEM). Berkaitan dengan hal tersebut, ukuran sampel untuk SEM yang menggunakan maximum likelihood estimation (MLE) adalah 100-200 sampel atau sebanyak 5 - 10 kali dari jumlah variabel yang diestimasi [15]. Oleh karena itu, jumlah responden yang diperlukan dalam penelitian ini sebaiknya adalah sebanyak 120 responden.

Variabel adalah sesuatu yang membedakan atau memvariasikan nilai [13]. Nilai tersebut dapat berbeda untuk waktu yang berbeda meskipun ditujukan pada objek atau orang yang sama.

Sesuai dengan model analisis yang digunakan dalam penelitian ini, yaitu Structural Equation Model (SEM), maka variabel yang digunakan meliputi variabel eksogen, variabel indikator (variabel terukur / measured variable / observed variable), dan variabel endogen. Tabel I berikut ini menjelaskan indikator dari masingmasing konstruk variabel.

TABEL I

DEFINISI KONSTRUK VARIABEL PENELITIAN

\begin{tabular}{|c|c|c|}
\hline Konstruk & Indikator & Kode \\
\hline \multirow{3}{*}{ Ease of use } & Struktur penyajian & $\mathrm{X} 1$ \\
\hline & Kemudahan akses & $\mathrm{X} 2$ \\
\hline & $\begin{array}{l}\text { Kejelasan } \quad \text { penyajian } \\
\text { informasi }\end{array}$ & $\mathrm{X} 3$ \\
\hline \multirow{2}{*}{ Customization } & Materi yang menarik & $\mathrm{X} 4$ \\
\hline & Personalisasi & X5 \\
\hline \multirow{2}{*}{$\begin{array}{l}\text { Donwload } \\
\text { delay }\end{array}$} & $\begin{array}{l}\text { Kecepatan menemukan } \\
\text { informasi }\end{array}$ & $\mathrm{X} 6$ \\
\hline & Kontrol terhadap materi & $\mathrm{X} 7$ \\
\hline \multirow[b]{2}{*}{ Content } & Spesifikasi informasi & $\mathrm{X} 8$ \\
\hline & $\begin{array}{l}\text { Pemenuhan kebutuhan } \\
\text { Kecukupan materi }\end{array}$ & $\begin{array}{l}\mathrm{X} 9 \\
\mathrm{X} 10\end{array}$ \\
\hline \multirow[b]{2}{*}{ Satisfaction } & Kenyamanan & $\mathrm{Y} 1$ \\
\hline & $\begin{array}{l}\text { Keinginan untuk } \\
\text { mengakses website }\end{array}$ & Y2 \\
\hline
\end{tabular}

Instrumen utama dalam penelitian ini adalah kuesioner. Pengukuran variabel dilakukan dengan menggunakan skala Likert, yaitu skala yang digunakan untuk mengukur sikap, pendapat dan 
persepsi seseorang dengan memberi skor kepada masing-masing alternatif jawaban.

Prosedur pengukurannya adalah responden diminta untuk menyatakan persetujuannya atas dasar persepsi masing-masing responden. Jawaban terdiri dari tujuh pilihan, yaitu : Sangat Sangat Tidak Setuju (SSTS), Sangat Tidak Setuju (TS), Tidak Setuju (TS), Ragu-ragu (R), Setuju (S), Sangat Setuju (SS), Sangat Sangat Setuju (SSS).

Pengisian form kuesioner tersebut akan direlasikan dengan NIK karyawan melalui LDAP TELKOM. Bila data NIK dan Password yang diisikan ternyata tidak sesuai dengan data LDAP TELKOM, maka data kuesioner tidak akan mencatatkan hasil kuesioner sebagai data yang valid. Selain itu, bila dari sekian banyak pertanyaan, tidak seluruhnya karyawan mengisi, maka data tersebut pun dianggap tidak valid.

Pemberian nilai (scoring) dilakukan untuk jawaban Sangat Sangat Setuju adalah nilai 7 demikian seterusnya menurun sampai pada jawaban Sangat Sangat Tidak Setuju yang diberi nilai 1. Bobot nilai jawaban responden dapat dilihat pada tabel II.

TABEL II

BOBOT NILAI JAWABAN RESPONDEN

\begin{tabular}{lcc}
\multicolumn{3}{c}{ BOBOT NILAI JAWABAN RESPONDEN } \\
\hline \hline Jawaban & Singkatan & Nilai \\
\hline Sangat sangat tidak setuju & SSTS & 1 \\
Sangat tidak setuju & STS & 2 \\
Tidak setuju & TS & 3 \\
Netral / tidak berpendapat & R & 4 \\
Setuju & S & 5 \\
Sangat setuju & SS & 6 \\
Sangat sangat setuju & SSS & 7 \\
\hline \hline
\end{tabular}

\section{Hasil dan Pembahasan}

Metode pengumpulan data seperti yang telah dijelaskan dalam bagian sebelumnya dengan menggunakan kuesioner. Dalam hal ini sebagai subjek responden adalah karyawan perusahaan yang juga adalah pelanggan atas produk dan layanan yang diberikan perusahaan kepada masyarakat. Hasil pengumpulan data berupa kuesioner yang berhasil disimpan dan layak untuk dianalisis dapat dilihat pada tabel III.

TABEL III

HASIL PENGUMPULAN DATA

\begin{tabular}{|c|c|c|}
\hline Keterangan & Jumlah & $\%$ \\
\hline $\begin{array}{l}\text { Kuesioner dengan user tidak } \\
\text { valid }\end{array}$ & 5 & 1.5 \\
\hline $\begin{array}{l}\text { Kuesioner pengisian tidak } \\
\text { lengkap }\end{array}$ & 16 & 4.7 \\
\hline Kuesioner memenuhi syarat & 318 & 93.8 \\
\hline Total & 339 & 100.0 \\
\hline
\end{tabular}

Jumlah kuesioner yang disebarkan kepada karyawan dengan sosialisasi melalui PORTAL Internal perusahaan. Didapat $5(1.5 \%)$ tidak valid setelah NIK ternyata tidak sesuai dengan password. Sebanyak 16 (4.7\%) tidak lengkap dan sisanya $318(93.8 \%)$ pengisiannya lengkap.

Mengacu pada dasar teori dalam penelitian ini, dapat dibuat diagram alur (path diagram) hubungan kausalitas antar konstruk beserta indikatornya. Path Analysis (Analisis Jalur) dikembangkan sebagai metode untuk mempelajari pengaruh (efek) secara langsung dan secara tidak langsung dari variabel bebas terhadap variabel tergantung.

Hubungan tersebut dapat dilihat pada gambar 4. Dalam penyusunan diagram alur tersebut, sebagaimana telah dijelaskan pada definisi operasional, terdiri dari 5 (lima) konstruk dan 12 (dua belas) indikator.

Model yang baik sangat dipengaruhi oleh validitas indikator dan reliabilitas konstruk. Oleh karena itu, perlu dilakukan pengujian terhadap validitas dan reliabilitas model dari data yang diperoleh.

Berdasarkan pembentukan persamaan struktural, berikutnya dilakukan measurement model. Dengan menggunakan aplikasi LISREL 8.80, data yang telah didapat dari hasil survei, kemudian dimasukkan ke dalam measurement model sebagaimana landasan teori pengukuran kepuasan pengguna. Hasilnya disajikan pada gambar 5.

Pengujian validitas digunakan untuk mengidentifikasi bahwa unobserved variable dapat diukur dengan menggunakan masingmasing konstruk observed variable melalui Confirmatory Factor Analysis (CFA) atau biasa disebut dengan analisis faktor. Apabila nilai factor loading dari tiap konstruk lebih dari $0,5(\lambda>0,5)$, maka dapat dinyatakan valid, atau dengan kata lain bahwa unobserved variable dapat diukur dengan menggunakan masing-masing konstruk observed variable. Hasil dari Pengujian Validasi ditunjukkan pada tabel IV.

Berdasarkan hasil estimasi sebagaimana ditunjukkan pada tabel IV, ternyata loading factor dari semua indikator tidak ada yang lebih kecil dari 0,50. Dengan demikian, maka semua indikator dinyatakan valid dan proses evaluasi model dapat dilanjutkan.

Peneliti melakukan uji reliabilitas dengan menghitung Cronbach Alpha dari masing-masing item dalam suatu variabel. Instrumen yang dipakai dalam variabel dikatakan handal (reliable) apabila memiliki Cronbach Alpha lebih dari 0,60 (Nunnaly, 1978).

Evaluasi terhadap reliabilitas pada model pengukuran, peneliti menggunakan composite 
reliability measure (ukuran reliabilitas komposit) dan variance extracted measure (ukuran ekstrak varian). Reliabilitas komposit suatu konstruk dihitung sebagai:

$$
\text { Construct_Re liability }=\frac{\left(\sum \text { std.loading }\right)^{2}}{\left(\sum \text { std.loading }\right)^{2}+\sum e_{j}}
$$

Sedangkan untuk Ekstrak Varian, dapat dihitung dengan rumus sebagai berikut:

$$
\text { Variance }_{-} \text {Extracted }=\frac{\sum \text { std.loading }^{2}}{N}
$$

Dari rumusan tersebut di atas, dapat dilihat hasil uji Reliabilitas Model Penelitian pada tabel V. Hasil perhitungan reliabilitas di atas dapat kita rangkum pada tabel $\mathrm{V}$ dan kita bisa melihat bahwa semua nilai Construct Reliability $(\mathrm{CR})>0.7$ dan semua nilai Variance Extracted (VE) > 0.50 . Dengan demikian kita bisa menyimpulkan bahwa reliabilitas model pengukuran (konstruk) adalah baik.

Hasil perhitungan model SEM sebagaimana ditunjukkan pada gambar 5 menghasilkan indeks goodness of fit sebagaimana ditunjukkan tabel VI.

Pengujian hipotesis. Dari model struktural yang terbentuk, diperoleh koefisien hubungan antar variabel didalamnya. Koefisien tersebut terdiri dari koefisien hubungan antar variabel laten dan nilai kontribusi dari variabel-variabel manifes pembentuk variabel laten tersebut. Hubungan yang terjadi pada model struktural ini merupakan dasar evaluasi terhadap hipotesis penelitian.

Tingkat signifikansi setiap hubungan antar variabel laten dilihat dari t-value harus lebih besar dari 1.96 untuk hubungan positif, dan kurang dari -1.96 untuk hubungan negatif (tingkat kepercayaan $\alpha=0.05)$. Berdasarkan hasil perhitungan tersebut diatas, maka peneliti perlu melakukan respesifikasi model untuk memperbaiki kecocokan model terhadap data [15].

Ease of use aplikasi dan kepuasan pengguna. Hipotesis pertama (H1) berbunyi : Kemudahan (Ease of Use) pada website aplikasi memiliki pengaruh positif langsung terhadap kepuasan pengunjung.

TABEL V

Hasil Uji Reliabilitas Model PeneltTian

\begin{tabular}{llll}
\hline \hline $\begin{array}{l}\text { Nama } \\
\text { variabel }\end{array}$ & CR & VE & Keterangan \\
\hline Ease of use & 0.8264 & 0.6146 & $\begin{array}{l}\text { Reliabilitas } \\
\text { baik }\end{array}$ \\
$\begin{array}{l}\text { Customization } \\
\text { beliabilitas }\end{array}$ & 0.7060 & 0.5475 & $\begin{array}{l}\text { baik } \\
\text { Reliabilitas } \\
\text { baik } \\
\text { Reliabilitas } \\
\text { baik } \\
\text { Reliabilitas } \\
\text { baik }\end{array}$ \\
$\begin{array}{l}\text { delay } \\
\text { Content }\end{array}$ & 0.7620 & 0.6176 & 0.8599 \\
Satisfaction & 0.7807 & 0.6429 & \\
\hline \hline
\end{tabular}

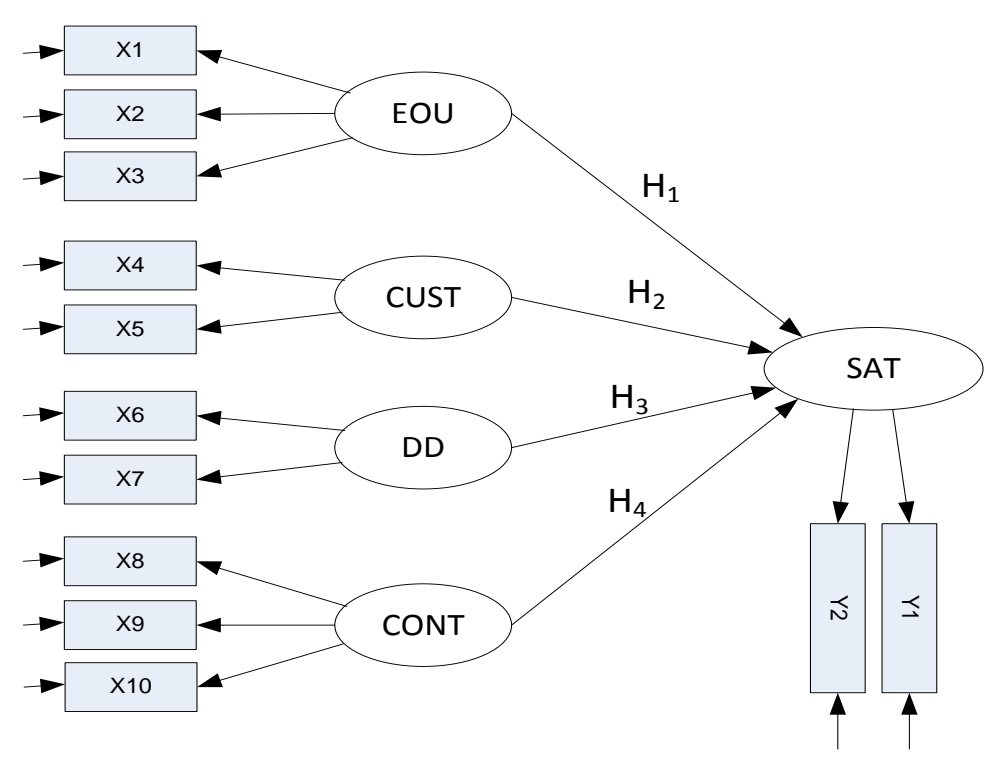

Gambar 4. Path analysis pada model penelitian. 


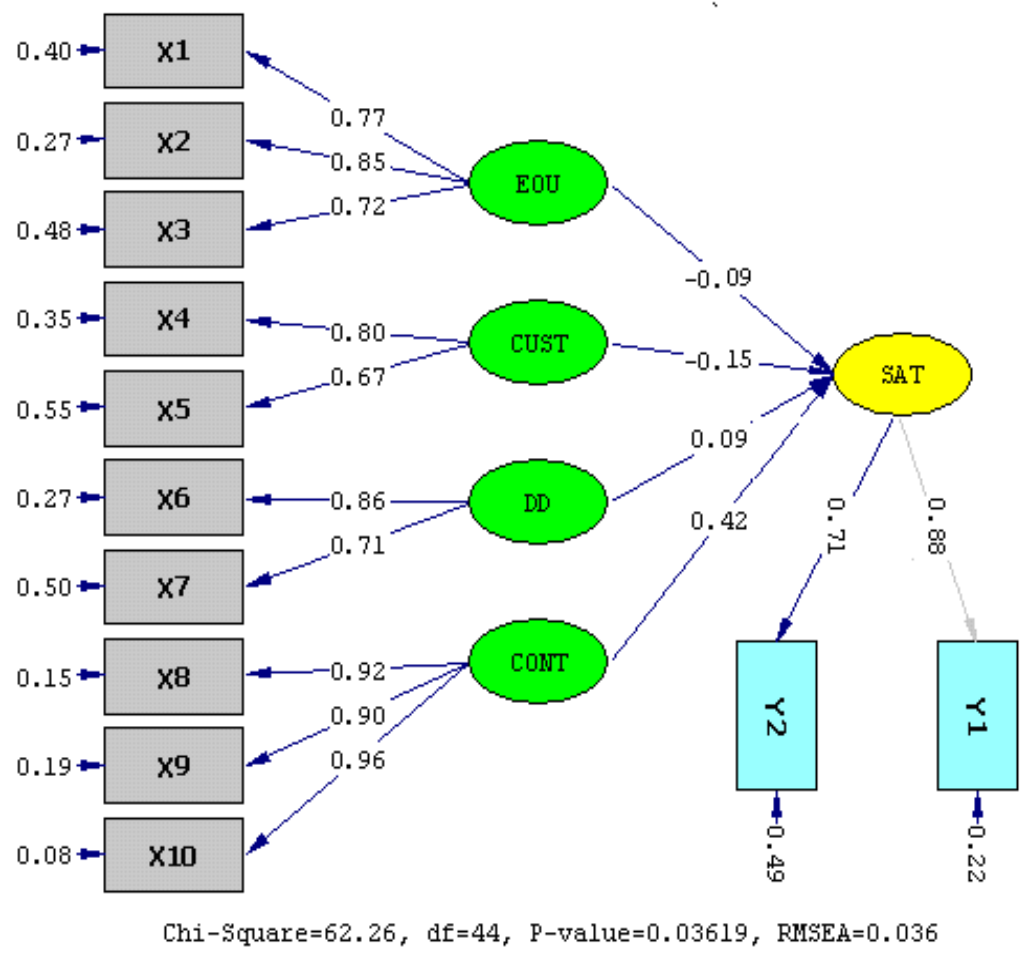

Gambar 5. Model struktural.

TABEL IV

NILAI LOADING FACTOR INDIKATOR

\begin{tabular}{|c|c|c|c|}
\hline Konstruk & Kode & \multicolumn{2}{|c|}{ Loading factor } \\
\hline \multirow{3}{*}{ Ease of use } & $\mathrm{X} 1$ & \multicolumn{2}{|c|}{0.77} \\
\hline & $\mathrm{X} 2$ & \multicolumn{2}{|c|}{0.85} \\
\hline & $\mathrm{X} 3$ & \multicolumn{2}{|c|}{0.72} \\
\hline \multirow[t]{2}{*}{ Customization } & $\mathrm{X} 4$ & \multicolumn{2}{|c|}{0.80} \\
\hline & $\mathrm{X} 5$ & \multicolumn{2}{|c|}{0.67} \\
\hline \multirow[t]{2}{*}{ Download delay } & $\mathrm{X} 6$ & \multicolumn{2}{|c|}{0.86} \\
\hline & $\mathrm{X} 7$ & \multicolumn{2}{|c|}{0.71} \\
\hline \multirow[t]{3}{*}{ Content } & $\mathrm{X} 8$ & \multicolumn{2}{|c|}{0.92} \\
\hline & $\mathrm{X} 9$ & \multirow{2}{*}{\multicolumn{2}{|c|}{$\begin{array}{l}0.90 \\
0.96\end{array}$}} \\
\hline & $\mathrm{X} 10$ & & \\
\hline \multirow[t]{2}{*}{ Satisfaction } & Y1 & \multicolumn{2}{|c|}{0.88} \\
\hline & $\mathrm{Y} 2$ & \multicolumn{2}{|c|}{0.71} \\
\hline \multicolumn{4}{|c|}{$\begin{array}{c}\text { TABEL VI } \\
\text { HASIL PERHITUNGAN INDEKS GOODNESS OF FIT }\end{array}$} \\
\hline Kriteria & $\begin{array}{c}\text { Hasil } \\
\text { model }\end{array}$ & $\begin{array}{l}\text { Nilai } \\
\text { kritis }\end{array}$ & 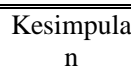 \\
\hline $\mathrm{X} 2$ - Chi square & 62.26 & Kecil & Diterima \\
\hline $\begin{array}{l}\text { Significance } \\
\text { probability }\end{array}$ & 0.03619 & $\geq 0,05$ & $\begin{array}{l}\text { Cukup } \\
\text { baik }\end{array}$ \\
\hline RMSEA & 0.036 & $\leq 0,08$ & $\begin{array}{c}\text { Baik } \\
\text { (Good fit) }\end{array}$ \\
\hline GFI & 0.97 & $\geq 0,90$ & $\begin{array}{l}\text { Baik } \\
\text { (Good fit) }\end{array}$ \\
\hline AGFI & 0.94 & $\geq 0,90$ & $\begin{array}{c}\text { Baik } \\
\text { (Good fit) }\end{array}$ \\
\hline CMIN/DF & 1.415 & $\leq 2,00$ & $\begin{array}{c}\text { Baik } \\
\text { (Good fit) }\end{array}$ \\
\hline TLI & 0.99 & $\geq 0,95$ & $\begin{array}{l}\text { Baik } \\
\text { (Good fit) }\end{array}$ \\
\hline CFI & 0.99 & $\geq 0,95$ & $\begin{array}{c}\text { Baik } \\
\text { (Good fit) }\end{array}$ \\
\hline
\end{tabular}

Hasil penelitian menunjukkan bahwa kemudahan dalam mengoperasikan Aplikasi (Ease of Use) tidak memiliki pengaruh positif secara langsung terhadap kepuasan (Satisfaction) pengunjung website ini. Temuan ini sama dengan hasil penelitian yang dilakukan oleh Aljukhadar dan Senecal [16], dimana dalam salah satu hipotesisnya, perceive ease of use merupakan salah satu variabel yang memiliki pengaruh pada suatu website, namun secara tidak signifikan memberikan pengaruh positif kepada kepuasan pengunjung.

Meskipun demikian, dari model penelitian yang telah dilakukan respesifikasi, dapat diketahui bahwa 3\% dari variasi aspek kepuasan pengunjung Aplikasi dijelaskan oleh aspek Ease of Use. Dalam model tersebut, diketahui pula bahwa aspek Ease of Use tersebut cenderung lebih memberikan pengaruh negatif atas kepuasan pengunjung website.

Untuk itu, manajemen perlu memahami, bahwa pengunjung website Aplikasi ini cenderung ingin menemukan suatu informasi yang lebih spesifik dan lebih tidak memerhatikansecara umum kemudahan untuk menggunakan atau mengoperasikan aplikasi.

Customization dan kepuasan pengguna. Hipotesis kedua (H2) berbunyi: Customization pada website aplikasi memiliki pengaruh positif langsung terhadap kepuasan pengunjung. Dalam hasil penelitian, Aspek ini menyajikan suatu 
informasi bahwa tampilan website dapat disajikan secara personal dan berbeda penyajiannya (customization) antar pengunjung yang satu dengan lainnya, pada website aplikasi.

Dari nilai koefisien pada hasil respesifikasi model penelitian, dapat diketahui bahwa $16 \%$ dari variasi aspek kepuasan pengunjung Aplikasi dijelaskan oleh aspek customization. Dalam model tersebut, diketahui pula bahwa aspek customization tersebut cenderung lebih memberikan pengaruh negatif atas kepuasan pengunjung website.

Sebagai pertimbangan bagi manajemen perusahaan dalam rencana pengembangan lebih lanjut pada Aplikasi, manajemen diharapkan dapat mempertimbangkan hasil hipotesis ini. Dalam bahasa yang lebih umum, pengunjung aplikasi ini tidak terlalu mementingkan kecepatan akses pada aplikasi.

Download delay dan kepuasan pengguna. Hipotesis ketiga (H3) berbunyi : Kecepatan Proses Aplikasi (Download Delay) pada website aplikasi memiliki pengaruh positif langsung terhadap kepuasan pengunjung.

Berdasarkan nilai koefisien pada hasil respesifikasi model penelitian, dapat diketahui bahwa $6 \%$ dari variasi aspek kepuasan pengunjung Aplikasi dijelaskan oleh aspek download delay ini. Dalam model tersebut, diketahui pula bahwa aspek download delay tersebut cenderung lebih memberikan pengaruh positif atas kepuasan pengunjung website.

Aspek ini memberikan suatu informasi bahwa kecepatan akses dan tampilan halaman pada website (download delay) dapat memberikan kontribusi terhadap kepuasan pengunjung website aplikasi.

Hasil hipotesis ini sependapat dengan hasil penelitian yang dikeluarkan oleh Green dan Pearson [12], bahwa download delay tidak memberikan pengaruh positif kepada kepuasan pengunjung suatu website.

Content dan kepuasan pengguna. Hipotesis keempat (H4) berbunyi : Isi materi (content) pada website Aplikasi memiliki pengaruh positif langsung terhadap kepuasan pengunjung. Aspek ini memberikan suatu penjelasan informasi bahwa isi materi suatu website (content) dapat memberikan kontribusi terhadap kepuasan pengunjung website.

Dari nilai koefisien pada hasil respesifikasi model penelitian, dapat diketahui bahwa $42 \%$ dari variasi aspek kepuasan pengunjung Aplikasi dijelaskan oleh aspek content. Dalam model tersebut, diketahui pula bahwa aspek content tersebut cenderung lebih memberikan pengaruh positif atas kepuasan pengunjung website.
Hasil hipotesis ini sependapat dengan hasil penelitian yang dikeluarkan oleh David Green dan Pearson [12], bahwa content memberikan pengaruh positif kepada kepuasan pengunjung suatu website.

Sebagai pertimbangandalam rencana pengembangan lebih lanjut, manajemen diharapkan dapat mempertimbangkan isi materi (content) pada aplikasi.

\section{Kesimpulan}

Berdasarkan hasil analisis, kesimpulan penelitian ini dapat dikemukakan menjadi beberapa pint. Pertama kemudahan menggunakan aplikasi (Ease of Use) tidak memiliki pengaruh positif secara langsung terhadap kepuasan (User Satisfaction) pengunjung website Aplikasi. Kedua, tampilan Informasi secara khusus untuk setiap Pengunjung website (Customization) tidak memiliki pengaruh positif secara langsung terhadap kepuasan (User Satisfaction) pengunjung website Aplikasi.

Ketiga, kecepatan akses data dan pemrosesan pada aplikasi (Download Delay) tidak memiliki pengaruh positif secara langsung terhadap kepuasan (User Satisfaction) pengunjung website Aplikasi. Keempat,sajian informasi terkait tarif produk dan layanan perusahaan (Content) memiliki pengaruh positif secara langsung terhadap kepuasan (User Satisfaction) pengunjung website Aplikasi dan pengaruh tersebut signifikan. Kelima, secara umum melalui analisis aspek usability dalam kerangka rencana pengembangan selanjutnya, Aplikasi masih perlu ditingkatkan dengan fokus pada Content (isi materi) yang lebih spesifik, lengkap dan memenuhi kebutuhan pelanggan terkait produk dan layanan perusahaan.

Saran-saran untuk perbaikan aplikasi dan penelitian yang dapat dilakukan lebih lanjut antara lain, pertama, mendesain ulang penyajian antarmuka aplikasi, termasuk melengkapi informasi produk dan layanan yang diberikan perusahaan kepada pelanggannya, khususnya untuk informasi berita promo produk terkini. Kedua, meningkatkan pemahaman atas tujuan publikasi aplikasi bagi pengguna, melalui paparan visi dan misi yang lebih jelas pada website agar ekspektasi pengunjung pun dapat sesuai dengan ruang lingkup layanan aplikasi. Ketiga, menyediakan bantuan (help atau user guide) secara online dan lebih informatif. Keempat, penelitian lebih lanjut dapat dikembangkan tidak hanya pada aspek usability, tapi juga pada aspekaspek user experience. Model penelitian ini dapat dikembangkan untuk aplikasi-aplikasi internet yang memiliki pengguna yang lebih banyak dan 
lebih luas cakupannya dengan menggunakan analisis dari responden yang lebih banyak.

\section{Referensi}

[1] U.S. Department of Health \& Human Services, Usability Basics, U.S. Government, http://www.usability.gov, retrieved November 13, 2009.

[2] H.C. Jetterand \& J. Gerken, A Simplified Model of User Experience for Practical Application, Universität Konstanz, http://www.inf.uni-konstanz.de/cgip/bib/ files/ JeGe06.pdf, 2006, retrieved March 28, 2008.

[3] H.S. Sastramihardja, "Perancangan Kerja dalam Perangkat Lunak, Interaktif," Jurnal Informatika ITB, vol.1, pp. 13-16, 1999.

[4] T.K. Landauer, The Trouble with Computers: Usefullness, Usability, and Productivity, MIT Press, Cambridge, 1995.

[5] P. Gonzalez, M.D. Lozano, \& F. Montero, "A Usability and Accessibility Oriented Development Process" University of Castilla-La Mancha, Spain, 2004.

[6] J. Nielsen, Guerrilla HCI: Using Discount Usability Engineering to Penetrate the Intimidation Barrier, Usable Information Technology, http://www.useit.com/papers/guerrilla_hci.ht $\mathrm{ml}$, 1994, retrieved January 29, 2008.

[7] A. Dix, J. Finlay, G. Abowd,R. \& Beale, Human-Computer Interaction, Prentice-Hall, New Jersey, 1993.
[8] A. Abran, A. Khelifi, W. Suryn, \& A. Seffah, "Consolidating the ISO Usability Models" 8th Annual INSPIRE Conference, 2003.

[9] J.W. Palmer, "WebSite Usability, Design and Performance Metrics,"Information Systems Research, vol. 13, pp. 151-167, 2002.

[10] R. Agarwal \& V. Venkatesh, "Assessing a Firm's Web Presence: A Heuristic Evaluation Procedure for the Measurement of Usability," Information Systems Research, vol. 13, pp. 168-186, 2002.

[11] D.T. Green \& J. M. Pearson, "Confirmatory Factor Analysis of Two Web SiteUsability Instruments" In Proceeding of the Third Annual Workshop on HCI Research, pp. 1011, 2004.

[12] D.T. Green \& J. M. Pearson, "The Examination of two web site usability instruments for use in B2C e-Commerce Organizations," Journal of Computer Information Systems, vol. 49, pp. 19-32, 2009.

[13] U. Sekaran, Research Methods for Business, a Skill-Building Approach, 2nd ed., John Wiley \& Sons, Inc., Canada, 1992.

[14] D.R. Cooper \& P. S Schindler, Business Research Methods, 8 ed., McGrawHill/Irwin, New York, 2003.

[15] S.H. Wijanto, Structural Equation Modeling dengan Lisrel 8.8 Konsep dan Tutorial, Graha Ilmu, Yogyakarta, 2008.

[16] M. Aljukhadar \& S. Senecal, "How the Website Usability Elements Impact Performance" Americas Conference on Information Systems, p.18, 2009. 